\title{
Goods and Services Tax: Issues and Challenges in India
}

\author{
Vikram Sandhu, Heena Atwal
}

\begin{abstract}
Number of indirect taxes is under one umbrella which simplifies taxation system for service and commodity businesses. GST can convey various advantages to economy as an indirect tax. The paper focuses on advantages to Indian economy, and various problems, issues and challenges in front of GST. These advantages include effect on GDP ratio, competitive advantages, price and consumption benefits and others. Present GST rates, exempted products from GST, issues and challenges are also discussed in this paper in which some problems such as lack of growth, complexity, filing charges, multiple returns are included.
\end{abstract}

Keywords: GST, Advantages of GST, GST Rates, problems, Issues and challenges in implementation process of GST.

\section{INTRODUCTION}

Goods and Service Tax (GST) is an indirect tax which has taken the place of many indirect taxes in India. It was passed on 29th March 2017 in the Parliament through the implementation of One Hundred and First Amendment of the Constitution of India by the Indian government but became effective on 1st July 2017. GST is supposed to be a dual levy system of taxation where both Central as well as State Government's will impose and collect taxes. The Centre will take charge of Central GST (CGST) and Integrated GST (IGST), while the State will take charge of State GST (SGST). This will help in bringing about economic unity, stability and transparency in the country. The common tax base would also help in preventing the system of double taxation system. There are various tax slabs for collection of tax $-0 \%, 5 \%, 12 \%, 18 \%$ and $28 \%$. But some products such as petroleum products, alcoholic drinks, and electricity are exempted from GST. Special rate is charged for rough precious and semi-precious stones @ $0.25 \%$ and $3 \%$ on gold. In addition a cess of $22 \%$ or other rates on top of $28 \%$ GST applies on few items like aerated drinks, luxury cars and tobacco products.Pre-GST, the statutory tax rate for most goods was about $26.5 \%$, Post-GST, most goods are expected to be in the $18 \%$ tax range. Various indirect taxes become under a single umbrella called GST. Moreover, the involvement of Information Technology through Goods and Service Tax Network (GSTN) would help in making things clear and convenient.

Revised Manuscript Received on September 25, 2019

* Correspondence Author

Dr.Vikram Sandhu, Assistant Professor, University Business School, Guru Nanak Dev University, Amritsar. Punjab. India.

Dr. Heena Atwal, Assistant Professor, Department of Basic and Applied Sciences, Punjabi University, Patiala. Punjab. India.

\section{LITERATURE REVIEW}

Dani, S. (2016) in her research study revealed that GST being a system replacing all indirect taxes might hamper the progress of the country as the attempt to implement it is not being made whole heartedly. Nayyar, A. and Singh, I. (2017) in their study cited that introduction of GST is a major breakthrough in the Indian economy. It will help in redefining the Indian Tax Structure by being more transparent and corruption free.

Abda, S. (2017) in his research paper concentrated on the objectives, purpose and benefits of GST to our economy and how it will help in strengthening it.

Yadav, S. S. and Shankar, R. (2018) in their research paper analysed the history and evolution of GST in the country and how it has replaced various indirect taxes. Rupa, R. (2017) in her research paper explained the concept of GST. Also she highlighted the advantages and disadvantages of GST in our economy. Kawle ,S, P. and Aher, L.,Y.(2017) in their research paper highlighted the working of GST in India along with its impact on the Indian economy.

Shefalidani (2016) stated impact of GST on Indian economy in the study in which some benefits of GST such as one nation one tax, free from cascading effect, increase consumption due to cascading effect, transparency and GDP growth are studied. Petroleum products, real estate, and liquor are free from GST.

Lourdunathan F and Xavier P. (2016) etudied inexplicit opinion of manufacturers, traders and society. It also included challenges and prospectus of GST in future in India. Centre and state level taxes also discussed in this paper. Various states are shown in which GST is followed for growth of economy. Some issues such demonetisation issue, inappropriate time, polictical issues, rate for manufacturers and traders, impact on working and cash flow and implementation in unorganised sectors became some main issues in path of GST.

B, MitraPriya (2017) stated GST as a Game changer in Indian Economy. The paper showed that GST reduced complexity of various taxes and also removed cascading effect. Tax structure shown in paper in which various tax rates included. Impact on Tax incidence included various sectors such as Telecom, E- Commerce, Automobile, real estate, banking and consumer goods. Impact on input tax credit showed that there would be availability of cross credit utilization in CGST and SGST.

Kapoor Kapil (2017) critically examined GST implementation, models, mechanism, issues and challenges. Development stages GST in India studied in this paper. Exclusions from GST which is petrol alcohal,

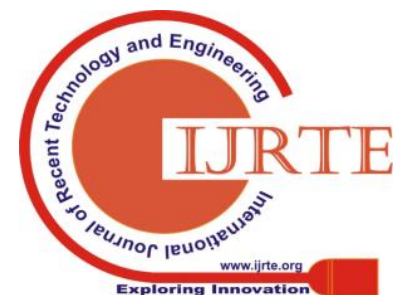


tobacco, Diesel and some benefits such as simplicity, transparency, cascading effect, reduction in burden of tax tax revenue collection, economic growth and no tax for exporters are included in this paper. Challenges also studied in the paper. So the paper concluded that proper implementation of GST will lead to economic growth.

\section{RESEARCH METHODOLOGY}

The research methodology of this paper includes sources from where data has been collected for research purpose. This part states objectives to be achieved by this paper. Some limitations are also included in this part.

3.1 Sources of Data Collection: The present study is exploratory in nature and is based on secondary data which has been collected through various published sources such as research journals, magazines, reports and online sources. After extensive review of literature, attempt has made to systematically present the issues and challenges of GST in India.

\subsection{Objectives of Study}

Following objectives have been framed and achieved in the study:

1. To examine the problems faced by the taxpayers in the compliance of GST.

2. To study GST rates and exempted products from GST.

3. To discuss the issues and challenges of GST in the implementation process in our country.

\subsection{Limitations of the study}

There are various other problems and issues but this study only focuses on some challenges and issues.

Data is collected from some databases to achieve only the objectives of the study.

The study used only secondary data for research purpose.

This is limited study due to time and cost constraint.

\section{DATA ANALYSIS}

This part of the study includes advantages of GST to economy in detail, and various problems, challenges and issues in implementation process of GST.

\subsection{Advantages}

There are three types of GST which is CGST (Central), SGST (state) and IGST (Integrated).

There are various benefits of GST are as follows:-

i. One taxation system for the whole country

ii. Number of indirect taxes is under one umbrella which simplifies taxation system for service and commodity businesses. So cascading effect of tax is removed.

iii. More transparent system of taxation

iv. The cost competitiveness of different goods and services would rise

v. GST helps to control black money due to mandatory check

vi. Consumption would rise as prices would fall

vii. Tax-GDP ratio will rise

viii. Supportive environment for undertaking business activities will be created. (Abda, S, 2017

\subsection{GST rates}

$5 \%$ for household necessities, coal, Indian sweets and life saving drugs.

$12 \%$ for computers and processed food

$18 \%$ for hair oil, toothpaste, soaps, capital goods and industrial intermediaries.

$28 \%$ for luxury items, cigarettes and aerated drinks and High end motorcycles

\subsection{Exempted items from GST}

1. hulled cereals

2. bones and horn cones

3. salt

4. Kajal, drawing books

5. sanitary napkins

6. branded vegetables

7. music books

8. palmyrajaggery

9. human hair

10. Dicalcium phosphate of animal feed

\subsection{Problems, Issues and Challenges}

1. Experts say that this GST model will not be able to increase growth and revenue as it will raise consumer price inflation. The price will include small proportion of tax which will raise price level and economy will suffer inflation situation. So there are more chances that there is lack of growth in revenue.

2. Dual GST system is very confusing, complex and complicated which is not very easy to understand by everyone. So there is more confusion among public or less educated public about IGST, CGST and SGST. So it is more complex.

3. There are some issues among CGST and SGST. Division of Central and State GST is still not clear.

4. For proper implementation of GST, there is need of sufficient infrastructure but our country still does not have a very strong IT network. Moreover, the internet connectivity is also not available in many parts of the country. So this insufficiency of infrastructure and internet facility become problem for GST.

5. Some products and services are still kept out of the league of GST. So there is game of vague tax net.

6. Assessees have to depend on the services and knowledge of the professionals such as Chartered Accountants to get all their work done. The assessees have to pay heavy fee to chartered accountant to file return.

7. Filing GST is a big hazard for the not so educated section of our country. Proper knowledge regarding importance and implementation of GST is lacking. Shifting for old taxation system to a totally new one requires lots of patience, hard work, time and knowledge

8. Multiple returns: The taxpayers have to file multiple returns under this system.

9. It might result in undue costs such as appointment of Chartered Accountants by the people who are not well versed with this system. Thus it increases cost of filing returns. 
10. The rules, regulations and provisions of this system are still ambiguous and not clear to major population of our country.

The country is still lacking skilled resources to carefully handle this taxation system.

\section{SUGGESTIONS AND RECOMMENDATIONS}

1. For better implementation and to face various challenges, focus must be on growth and development aspect. Efforts should be made to increase the revenue and growth of the economy by overcoming challenges which are faced. Inflation should also be kept under strict check so that better and improved policies and rules can be formulated to maintain price sustainability.

2. There must be such type of system so that complexity in filing GST can be reduced. The lengthy and complex procedure of documentation formalities about GST should be reduced and must be in simplified form.

3. Strengthening IT Network and Infrastructure: Very strong IT network for GST has to be formulated such as collection of data, maintaining database and protection of information is a very crucial task.

4. Providing proper and deep knowledge: Even a common man should be well versed with the importance and role of GST. Moreover, he should have proper knowledge about various documents required and all the rules relating to GST and its filing.

5. Proper skilled resources should be engaged to implement the system. Skill development programmes, training and refresher courses must be provided so that updated knowledge can be imparted.

6. Free of cost workshops or training camps should be set up to help people understand the whole process of return filing in this system.

7. The division and grouping of products under different heads and rate of tax should be clearly defined without any confusion. So there must be clarification for each and every aspect of GST.

\section{CONCLUSION}

The study provides some recommendations regarding GST. It stated GST rates and exempted products. The study concludes that the new taxation system of GST has its own problems and challenges as it is in its initial stage. But if this system is properly and effectively implemented, then it can help in improving the financial and economic position of our country. This system is considered as a more transparent and improved version of taxation system. But the actual impact and relevance will be known as time passes by.

\section{SCOPE FOR FURTHER RESEARCH}

The study tried to discuss the topic very deeply and widely but every study leaves some scope for further improvements and research. This paper is theoretical in nature. So, an attempt can be made to empirically investigate and validate the factors affecting the issues and challenges of GST. The opinion of experts and taxpayers can be analysed through a questionnaire and inquiring about the difficulties faced in the process of implementation of GST.

\section{REFERENCES}

[1] Abda, S.(2017)Research paper on effects of goods and services tax on indian economy. International education and research journal, 3(5), 584-585.

[2] B, MitraPriya. (2017). GST-A Game Changer, International Journal of Management Research and Social Science (IJMRSS), vol. 4(1), pp. $10-12$.

[3] Dani, S., (2016). A Research Paper on an Impact of Goods and Service Tax (GST) on Indian Economy. Business and Economics Journal, Bus Eco J 7: 264. doi: 10.4172/2151-6219.1000264.

[4] Kapil Kapoor (2017). GST New Tax Regime: Issues and Challenges. International journal of recent scientific research, vol. 8(4), pp. 1678616790.

[5] Kawle ,S, P. and Aher, L.,Y.(2017). GST: An economic overview: Challenges and Impact ahead. International Research Journal of Engineering and Technology, Volume: 04 Issue: 04, pp. 2760-2763.

[6] Lourdunathan F and Xavier P (2016). A study on implementation of goods and services tax (GST) in India; Prospectus and challenges, International Journal of Applied Research, vol. 3(1), pp. 626-629.

[7] Nayyar, A. and Singh, I. (2017). A Comprehensive Analysis of Goods and Services Tax (GST) in India. Indian Journal of Finance, DOI: 10.17010/ijf/2018/v12i2/121377.

[8] Rupa, R.(2017).Gst in india: an overview. international education and research journal, https://www.researchgate.net/publication/315331885.

[9] Shefali Dani (2016). a RESEARCH PAPER ON AN IMPACT OF GOODS AND SERVICE TAX ON INDIAN ECONOMY. BUSINESS and economics journal, vol. 7 (4). DOI: 10.4172/2151-6219.1000264.

[10] Yadav,S., S. and Shankar, R. (2018). "Goods and service tax (GST): how and why", Journal of Advances in Management Research, Vol. 15 Issue: 1, pp.2-3.

[11] http://www.gstcouncil.gov.in/

[12] http://www.gstindia.com/

[13] http://www.gstindia.com/basics-of-gst-implementation-in-india/

[14] https://en.wikipedia.org/wiki/Goods_and_Services_Tax_(India) 